\title{
RESILIENSI KELUARGA MELALUI PEMBERDAYAAN EKONOMI PERAN IBU DI MASA PANDEMI
}

\author{
Ignasius Heri Satrya Wangsa ${ }^{1)}$ \\ Prodi Manajemen, Fakultas Bisnis \& Akuntansi, Universitas Katolik Musi Charitas, \\ email: ig_heri@ukmc.ac.id
}

Agustinus Riyanto $^{2)}$

Prodi Psikologi, Fakultas Humaniora \& Ilmu Pendidikan, Universitas Katolik Musi Charitas, email: a_riyanto@ukmc.ac.id

Maria Josephine Tyra ${ }^{3)}$

Prodi Manajemen, Fakultas Bisnis \& Akuntansi, Universitas Katolik Musi Charitas, email: tyra@ukmc.ac.id

\section{Lina $^{4)}$}

Prodi Manajemen, Fakultas Bisnis \& Akuntansi, Universitas Katolik Musi Charitas, email: lina@ukmc.ac.id

\section{Johan Gunady Ony ${ }^{5)}$}

Prodi Manajemen, Fakultas Bisnis \& Akuntansi, Universitas Katolik Musi Charitas, email: johangunadyony@ukmc.ac.id

\section{Maria Ignasia Galuh Parwati'}

Prodi Psikologi, Fakultas Humaniora \& Ilmu Pendidikan, Universitas Katolik Musi Charitas, email: galuhprwti17@gmail.com

\begin{abstract}
The present pandemic has changed the global economic life. In the family level it results the decreasing family income. This situation weakens the resilience. Therefore. it is urgent to create new opportunities within the context of family. Family has played major role where the mother's involvement is significant to respond the change and to creatively look for entrepreneurship opportunity. This community service aims at improving the family resilience through economic empowerment of mother's role. The activity is divided into two sessions, namely: (1) Practical skills of child independence development; and (2) Practical entrepreneurship skills "how to make peach gum herbal drink". Survey was conducted at the end of the activity. One-Sample Test was employed to measure means value of perceived-benefit, involvement and loyalty which is accounted for 4 (= Agree) (Sig. > 0.05). Procedures for Bivariate Correlation to measure the participation level was applied. The result shows significant correlation between Session Attractiveness (KTM) and Perceived-benefit (PMM) (0.548/Sig. 0.01), and between Future Intention (KKG) and Recommendation (KR) (0.447/Sig. 0.05).
\end{abstract}

Keywords: family resilience, entrepreneurship, mother's role 


\begin{abstract}
ABSTRAK
Dampak pandemi yang sedang berlangsung saat ini telah merubah tatanan global kehidupan ekonomi. Di tingkat keluarga berdampak pada penurunan tingkat pendapatan keluarga. Situasi ini melemahkan daya resiliensi. Disini perlu diciptakan peluang-peluang baru. Dalam konteks ini keluarga menjadi sentral dimana peran ibu diberdayakan untuk tanggap terhadap perubahan sekaligus kreatif dalam mencari peluang kewirausahaan. Kegiatan pengabdian kepada masyarakat ini dilakukan untuk meningkatkan resiliensi keluarga melalui pemberdayaan ekonomi peran ibu. Bentuk kegiatan berupa pelatihan yang dibagi menjadi dua sesi, masing-masing: (1) Pelatihan ketrampilan pendidikan kemandirian anak; (2) Pelatihan ketrampilan wirausaha pembuatan minuman herbal "peach gum". Di akhir kegiatan dilakukan survei tingkat partisipasi peserta. Dengan menggunakan prosedur One-Sample Test diketahui skor rata-rata persepsi terhadap manfaat, keterlibatan dan keinginan untuk merekomendasi kegiatan sebesar 4 (= Setuju) (Sig. > 0.05). Demikian juga dengan Korelasi Bivariate diketahui Nilai Pearson Correlation sebesar 0.548 (Sig. 0.01) menunjukkan hubungan antara Ketertarikan terhadap Materi (KTM) dan Persepsi Materi memiliki Manfaat (PMM), serta Nilai Pearson Correlation sebesar 0.447 (Sig. 0.05) menunjukkan hubungan antara Keinginan mengikuti Kegiatan serupa di masa mendatang (KKG) dan Keinginan Merekomendasi kegiatan kepada orang lain (KR).
\end{abstract}

Kata Kunci: resiliensi keluarga, kewirausahaan, peran ibu

\section{PENDAHULUAN}

Dampak pandemi yang sedang berlangsung saat ini telah merubah tatanan global kehidupan ekonomi. Di Indonesia kelesuan perekonomian ditunjukkan oleh kelambatan laju pertumbuhan ekonomi sebesar $2.35 \%$ yang terutama disebabkan oleh kenaikan angka pengangguran. Data dari Kementerian Tenaga Kerja Republik Indonesia menunjukkan total jumlah pekerja dirumahkan mencapai $1,943,916$ orang dari 114,340 perusahaan (Kemnaker, 2020). Situasi ini berdampak secara langsung pada penurunan tingkat pendapatan keluarga. Prime et al (2020) juga menegaskan pandemi memberi dampak sosial ekonomi berkepanjangan bagi keluarga dan anak-anak, dan oleh karenanya perlu dicarikan sebuah solusi terutama untuk meningkatkan resiliensi keluarga.

Menurut Masten (2018) dalam Kimhi et al (2020) resiliensi adalah potensi kapasitas sebuah sistem dinamis yang dapat diwujudkan untuk beradaptasi dengan baik terhadap segala gangguan yang mengancam fungsi, daya tahan, maupun perkembangan sistem tersebut. Resiliensi berkaitan dengan sebuah fungsi alami individu memonitor kemampuan seseorang untuk bertahan ketika menghadapi tekanan dan keberagaman.

Dalam ruang lingkup keluarga resiliensi dibentuk melalui kualitas sikap ketangguhan, kegigihan dan kreatifitas menciptakan peluangpeluang baru yang memiliki nilai tambah ekonomis. Pandangan hakikat wanita yang memiliki modal sosial jejaring (Puspitasari, 2012) menyebutkan hakikat (nature) dan kemampuan wanita untuk berelasi sekaligus membentuk jejaring sosial dapat menjadi sebuah peluang bernilai ekonomis. Ini mengindikasi bahwa ketika wanita memasuki ranah keluarga, menjadi seorang ibu dalam konsepsi partnership (bersama suaminya) untuk mengelola ekonomi keluarga (Puspitasari, 2012), maka diperlukan pemahaman bahwa segala peluang bernilai ekonomis tersebut sebagai kesempatan untuk menambah pendapatan sekaligus meningkatkan kesejahteraan keluarga. Dengan demikian resiliensi keluarga diarahkan kepada pembentukan ketahanan secara ekonomis menghadapi nilai-nilai baru melalui penciptaan peluang kemandirian usaha. Keluarga menjadi satu tim solid untuk saling bekerjasama dalam kesamaan persepsi mengelola sumber daya bernilai ekonomis dengan memaksimalkan 
peran masing-masing. Dalam konteks ini keluarga yang mempraktekkan kemandirian usaha sebagai proses maksimalisasi pemberdayaan potensi ekonomi secara kolektif.

Menurut Long (1983:54) kemandirian usaha adalah kemampuan mengeksplorasi sebuah peluang sekaligus mengambil keuntungan di dalamnya. Sebuah peluang tidak begitu saja dapat dikenali keberadaannya, dan

oleh karenanya tidak dapat dengan mudah diketahui keuntungan yang dapat diambil daripadanya, tanpa adanya sebuah fungsi kesadaran kemandirian usaha.

Beberapa atribut kualitas kemandirian usaha meliputi (Long, 1983:55): kemampuan mempekerjakan diri sendiri (self-employed) dengan mengikuti tren permintaan pasar, keberanian menghadapi berbagai halangan dan ketidakpastian, kemampuan menjalankan fungsi manajerial dasar untuk mengarahkan serta mengendalikan, kemampuan mengidentifikasi dan memberdayakan gagasan yang memiliki peluang bagi perluasan sebuah sumber daya ekonomis.

Pengabdian kepada masyarakat ini bertujuan untuk meningkatkan daya resiliensi keluarga melalui pemberdayaan ekonomi peran ibu dengan melakukan pembekalan ketrampilan praktis mempersiapkan kemandirian anak dan pengelolaan sumber daya ekonomis. Bentuk kegiatan berupa pelatihan yang dibagi menjadi dua sesi, masing-masing: (1) Ketrampilan praktis pendidikan kemandirian anak; dan (2) Ketrampilan wirausaha pembuatan minuman herbal "peach gum".

\section{METODE PELAKSANAAN}

Peserta pelatihan program resiliensi keluarga melalui pemberdayaan ekonomi peran ibu ini berjumlah 30 (tiga puluh) orang. Mereka adalah para ibu rumah tangga dengan rentang usia antara 48 s/d 55 tahun, tergabung dalam keanggotaan Wanita Katolik Republik Indonesia (WKRI) serta berdomisili di Wilayah Paroki Gereja Santo Petrus - Kenten Palembang. Pelaksanaan kegiatan dilakukan pada hari Minggu (21/3/2020) mulai Pk. 15.00 - 17.30. Dipilihnya hari Minggu adalah pertimbangan fleksibilitas waktu bagi peserta agar dapat mengikuti program resiliensi keluarga ini secara lengkap.

Kegiatan dibagi menjadi dua sesi utama. Sesi pertama berupa penyuluhan tentang ketrampilan praktis pendidikan kemandirian anak. Dilanjutkan dengan sesi kedua berupa ketrampilan wirausaha pembuatan minuman herbal "peach gum".

Pada kegiatan sesi pertama (Gambar-1 dan Gambar-2) dijelaskan poin-poin penting dalam pendidikan kemandirian anak berikut contoh kasus dan penyelesaiannya. Kemudian peserta diberi waktu untuk bertanya dan memberikan pendapat. Isi materi ditekankan pada pembentukan sikap kemandirian sebagai potensi dasar bagi anak untuk semakin menyadari bahwa dalam dirinya terdapat sumber daya bernilai ekonomis yang dapat dipertukarkan dan dikontribusikan bagi peningkatan ekonomi keluarga.

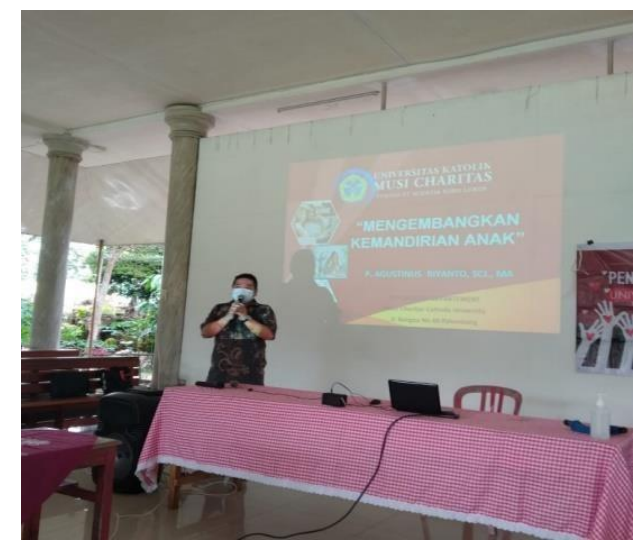

Gambar 1: Kegiatan Sesi-1 (Pengantar)

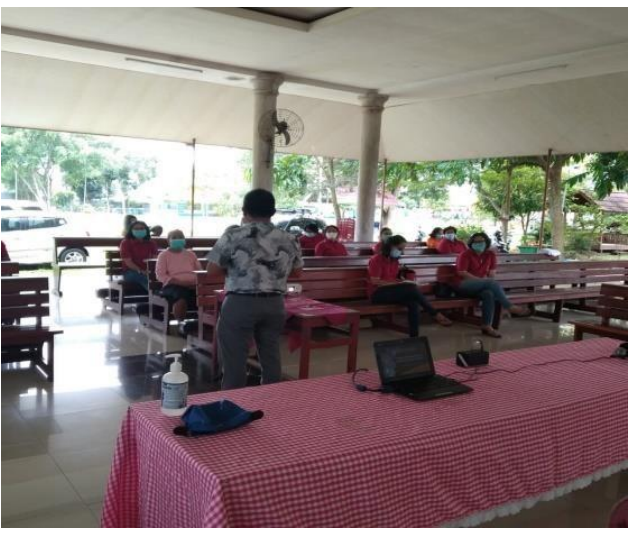

Gambar-2: Kegiatan Sesi-1 (Pemaparan materi) 
Berikutnya, pada sesi kedua diperagakan cara pembuatan minuman herbal "peach gum" (Gambar-3). Pada sesi ini pemaparan dilakukan dengan menggunakan teknik peragaan. Kedua sesi tersebut kemudian dilanjutkan dengan pembahasan kesimpulan dan pembentukan jejaring sosial sebagai tindak lanjut dari kegiatan pengabdian kepada masyarakat ini (Gambar-4).

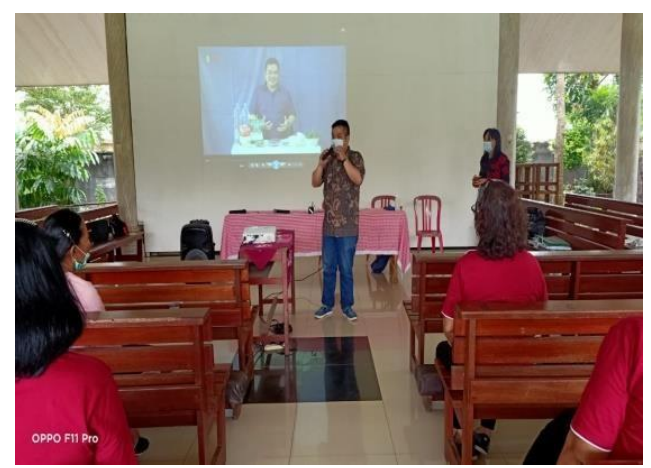

Gambar-3: Kegiatan Sesi-3 (Peragaan)
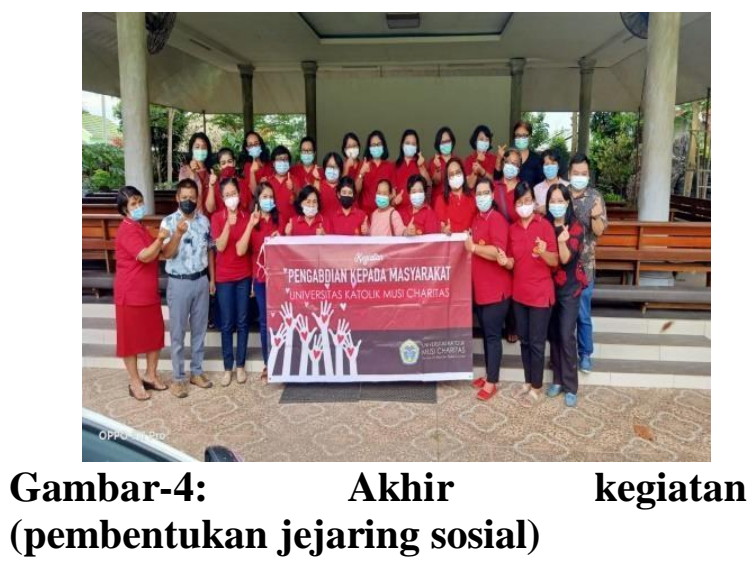

Pada akhir kegiatan disiapkan kuesioner dengan 10 (sepuluh) item pernyataan yang dikembangkan melalui tiga konsep, yaitu: (1) Konsep persepsi manfaat jasa (Kinard \& Capella, 2006) meliputi item \# 1 (Aku mengerti materi yang disampaikan oleh para pembicara), item \# 2 (Aku mengambil manfaat dari materi yang disampaikan oleh para pembicara), item \# 3 (Aku mempunyai alasan kuat untuk datang ke tempat ini), item \# 4 (Aku mempunyai alasan kuat untuk mendengarkan dengan baik materi yang disampaikan oleh para pembicara), item \# 5 (Aku mempunyai alasan kuat untuk tertarik terhadap materi yang disampaikan oleh para pembicara); (2) Konsep keterlibatan konsumen (Beatty et al, 1988) meliputi item \# 6 (Aku mengatur waktu dengan baik untuk datang ke tempat ini), item \# 7 (Aku terlibat aktif untuk bertanya ataupun menanggapi terhadap materi yang disampaikan oleh para pembicara), item \# 8 (Aku mencoba menghubungkan materi yang disampaikan oleh para pembicara dengan kehidupanku seharihari); (3) Konsep loyalitas konsumen ( McMullan \& Gilmore, 2008) meliputi item \# 9 (Aku akan mengikuti kegiatan serupa di masa mendatang), item \# 10 (Aku akan memberitahu orang lain akan pentingnya kegiatan seperti ini). Kuesioner tersebut kemudian dipakai untuk melakukan survey tingkat partisipasi peserta. Selanjutnya data dalam isian kuesioner diolah dengan menggunakan Analisis Deskriptif prosentase skor rata-rata tanggapan, One-Sample Test dan Analisis Korelasi Bivariate.

\section{HASIL DAN PEMBAHASAN}

Anak merupakan aset keluarga. Penanaman nilai-nilai kemandirian anak sejak dini akan membantu perkembangan anak ketika berusia dewasa. Keluarga memiliki otoritas untuk terlibat dalam penanaman nilai-nilai kemandirian tersebut dengan menciptakan lingkungan dimana anak dapat mengenal tanggungjawab terhadap diri dan masa depannya. Kelak ketika anak mulai beranjak dewasa, maka otoritas keluarga tersebut dikurangi. Anak-anak kemudian mulai dibebaskan untuk mengalami kehidupan sebagai individu yang punya tanggungjawab mengelola sumber daya bernilai ekonomis bagi masa depannya.

Pada sesi pertama kegiatan Pengabdian Kepada Masyarakat disampaikan hal-hal praktis berkaitan dengan pendidikan nilai kemandirian anak. Sesi diawali dengan cerita pengalaman para peserta dalam mengasuh dan membimbing anak. Pengalaman ini kemudian dihubungkan dengan teori mengenai kemandirian anak yang disampaikan oleh pemateri. Melalui pendekatan praktis-teoritis orientasi wawasan peserta diarahkan kepada pola pikir kritis (critical thinking) sekaligus bernilai ekonomis; bahwa 
kemandirian anak mempunyai nilai strategis dan investasi bagi masa depan keluarga.

Sesi kedua diisi dengan peragaan pembuatan minuman herbal "peach gum". Sesi ini diawali dengan pendalaman pengertian kemandirian usaha (entrepreneurship) melalui penjelasan empat atribut sebagaimana dikemukakan oleh Long (1983:55), masingmasing adalah: (1) Kejelian (mengikuti tren permintaan pasar); (2) Kesanggupan (menghadapi turbulensi halangan dan ketidakpastian); (3) Kecakapan (pengelolaan aset-aset strategis); (4) Kecermatan (mengidentifikasi sekaligus memberdayaan gagasan yang memiliki peluang). Pada sesi ini peserta dibagi menjadi beberapa kelompok untuk mendiskusikan keempat atribut kemandirian usaha. Diskusi diarahkan untuk memperdalam pengertian atribut kemandirian usaha, serta cara praktis meningkatkan kualitas kemandirian usaha (entrepreneurship quality).

Pemateri menjelaskan bahwa dipilihnya pelatihan pembuatan minuman "peach gum" berdasarkan penerapan kualitas kemandirian usaha melalui rasionalisasi: (1) Kejelian mengikuti selera pasar yang membutuhkan sebuah solusi dalam situasi pandemi. Minuman herbal "peach gum" menawarkan sebuah solusi karena pertimbangan: manfaat bagi kesehatan ie. pembentukan imun tubuh, dibuat dari bahan yang mudah didapatkan, relatif mudah pembuatannya, serta dapat diproduksi dalam jumlah yang cukup bagi peningkatan pendapatan keluarga; (2) Kesanggupan menghadapi berbagai permasalahan maupun kesulitan dalam proses pembuatan dan pemasarannya. Dijelaskan bahwa dalam bisnis selalu muncul ketidakpastian (uncertainty) yang justru dihadapi dengan menciptakan sebuah peluang; (3) Kecakapan merupakan ketrampilan yang bersifat integratif teori-terapan. Dalam rasionalisasi ini kerangka konseptual digali dan dipahami kemudian dihubungkan dengan temuan-temuan praktis; (4) Kecermatan memunculkan sebuah gagasan melalui kajian perilaku pasar (market behavior), kemudian mengoperasionalisasikan dalam tingkatan praktis. Berikutnya, dilakukan sosialisasi pembentukan jaringan sosial-ekonomi (socioeconomic networking) dimana peserta dimotivasi untuk saling bekerjasama dan berkolaborasi melakukan "pertukaran strategis" sumber daya bernilai ekonomis. Ini merupakan manifestasi kelanjutan dari kegiatan pengabdian kepada masyarakat.

Kegiatan Pengabdian Kepada Masyarakat ini diakhiri dengan pengumpulan data tanggapan peserta. Melalui Analisis Deskriptif (Lampiran-2) prosentase tanggapan peserta (Skor 5 = Sangat Setuju; Skor $4=$ Setuju) dapat dijelaskan sebagai berikut: (1) Materi dapat dimengerti (Skor 5) (50\%); (2) Materi memiliki manfaat (Skor 5) (56.7\%); (3) Kegiatan ini perlu diikuti (Skor 4) (66.7\%); (4) Paparan pemateri perlu disimak (Skor 5) (50\%); (5) Materi menarik (Skor 4) (53.3\%); (6) Mempersiapkan diri untuk mengikuti kegiatan (Skor 5) (53.3\%); (7) Terlibat aktif selama kegiatan (Skor 4) (76.7\%); (8) Berusaha memahami materi (Skor 4) (66.7\%); (9) Keinginan mengikuti kegiatan serupa di masa mendatang (Skor 4) (63.3\%); (10) Keinginan merekomendasi kegiatan ini kepada orang lain (Skor 4) (63.3\%). Selanjutnya dilakukan Analisis One-Sample Test (Lampiran-3) untuk melihat apakah nilai rata-rata dari setiap item kuesioner, atau tanggapan peserta, skor rataratanya dapat dikatakan sama dengan 4 (= Setuju). Hasil penghitungan menunjukkan nilai rata-rata dari setiap item kuesioner terbukti tidak berbeda dengan 4 (H0 tidak dapat ditolak dengan tingkat signifikansi dibawah 0.05). Dengan demikian kegiatan dapat dikatakan direspon dengan baik oleh peserta.

Analisis Korelasi Bivariate (Lampiran-4) dilakukan untuk melihat korelasi antara Persepsi Materi memiliki Manfaat (PMM) (item \# 2) dan Ketertarikan Terhadap Materi (KTM) (item \# 5). Hasil penghitungan menunjukkan Nilai Pearson Correlation 0.548 (Sig. < 0.01). Ini membuktikan bahwa ketertarikan peserta terhadap materi yang disampaikan dalam kegiatan tersebut disebabkan oleh persepsi bahwa materi memiliki manfaat. Peserta telah menyadari dengan baik adanya manfaat dalam kegiatan Pengabdian Kepada Masyarakat ini. Analisis Korelasi Bivariate juga digunakan untuk mengetahui loyalitas peserta terhadap kegiatan ini. Hasil penghitungan menunjukkan terdapat korelasi antara Keinginan mengikuti 
Kegiatan serupa di masa mendatang (KKG) dan Keinginan Merekomendasi kegiatan kepada orang lain (KR) dengan Nilai Pearson Correlation sebesar 0.447 (Sig. < 0.05). Peserta memiliki loyalitas terhadap kegiatan, sekaligus berharap untuk dapat diselenggarakan kembali kegiatan serupa di masa mendatang.

\section{SIMPULAN}

Kegiatan pengabdian kepada masyarakat ini memiliki nilai strategis memperluas wawasan peserta tentang pemberdayaan ekonomi keluarga melalui peran ibu dalam memberi perhatian terhadap kemandirian anak; sekaligus kemampuan menciptakan peluang kemandirian usaha (entrepreneurship). Peran ibu menjadi sentral dalam konsep partnership dimana tanggung jawab pemberdayaan ekonomi keluarga dibagikan kepada anggota keluarga yang lain. Kegiatan ini dapat dilanjutkan dengan topik dan peserta yang beragam seputar pemberdayaan ekonomi keluarga. Pendekatan interaktif-praktis perlu dikembangkan supaya materi dapat dipahami dan diterima dengan keterlibatan yang aktif dari peserta. Kegiatan juga perlu diawali dan diakhiri dengan penjelasan tentang manfaat kegiatan.

\section{UCAPAN TERIMAKASIH}

Ucapan terimakasih kepada seluruh pihak yang membantu kelancaran pelaksanaan kegiatan Pengabdian Kepada Masyarakat ini:

(1) Kepala LPPM Universitas Katolik Musi Charitas - Palembang; (2) Romo Paroki Gereja Katolik Santo Petrus Kenten - Palembang; (3) Ketua Wanita Katolik Republik Indonesia (WKRI) Paroki Gereja Katolik Santo Petrus Kenten - Palembang; (4) Semua pihak terkait.

\section{REFERENSI}

[1] Beatty, S.E., Homer, P. \& Kahle, Lynn, R. (1988) The involvement - commitment model: Theory and implications. Journal of Business Research, Vol. 16, No. 2, pp. 149-167

[2] Kementerian Ketenagakerjaa Republik Indonesia (Kemnaker), 2020

[3] Kimhi, S., Marciano, H., Eshel, Y \& Ardini, B. (2020) Recovery from the
Covid-19 pandemic: distress and resilience. International Journal of Disaster Risk Reduction, 50 (2020) pp. 1-7

[4] Kinard, B.R. \& Capella, M.L. (2006) Relationship marketing: the influence of consumer involvement on perceived service benefits. Journal of Service Marketing, Vol 20, No. 6 pp. 359-368

[5] Long, W. (1983) The meaning of entrepreneurship. American Journal of Small Business, Vol. VIII, No. 2, Oct-Des. 1983, pp. 47-59

[6] McMullan, R. \& Gilmore, A. (2008) Customer loyalty: an empirical study. European Journal of Marketing, Vol. 42, No. 9/10, pp. 1084-1094

[7] Masten, A.S. (2018) Resilience theory and research on children and families: Past, present, and promise. Journal of Family Theory \& Review / Vol. 10, Issue 1 / pp. 12-31

[8] Prime, H., Browne, D.T. \& Wade, M. (2020) Risk and resilience in family wellbeing during the Covid-19 pandemic. American Psychologist, Vol. 75, No. 5, pp. 631-643

[9] Puspitasari, D.C. (2012) Modal sosial perempuan dalam peran penguatan ekonomi keluarga. Jurnal Pemikiran Sosiologi, Vol. 1 No. 2 November 2012 pp. $69-80$ 